\title{
Differentiation of Saccharomyces cerevisiae at Slow Growth Rates in Glucose-limited Chemostat Culture
}

\author{
By V. C. BUGEJA, * J. R. PIGGotT and B. L. A. CARTER \\ Department of Genetics, University of Dublin, Trinity College, Dublin 2, Ireland
}

(Received 1 March 1982; revised 14 May 1982)

\begin{abstract}
Saccharomyces cerevisiae was grown in a glucose-limited chemostat at dilution rates equivalent to mass doubling times of 2 to $16 \mathrm{~h}$. Phase contrast microscopy revealed that cultures with mass doubling times greater than $4.5 \mathrm{~h}$ contained two sub-populations of cells, phase-dark and phaselight. The latter were shown to be predominantly unbudded daughter cells, which were not proliferating, and had properties similar to those of stationary phase cells in batch culture. Phase-dark cells were equivalent to cells growing exponentially in batch culture. The results suggest that the formation of phase-light cells represents cell cycle specific differentiation into stationary phase. The consequences of this phenomenon for the interpretation of results obtained with $S$. cerevisiae in the chemostat are discussed.
\end{abstract}

\section{INTRODUCTION}

Chemostat studies of the cell cycle of Saccharomyces cerevisiae at different growth rates have shown that at slow growth rates, not all the cells in the population have the same interdivision time (von Meyenberg, 1968; Jagadish \& Carter, 1977; Jagadish et al., 1977; Carter \& Jagadish, 1978 $a, b$; Johnston et al., 1979; Thompson \& Wheals, 1980). Parent cells (those which have previously produced a bud) divide with an interdivision time that is less than the mass doubling time of the culture, whereas daughter cells (those which have not previously produced a bud) divide with an interdivision time that is greater than the mass doubling time of the culture.

In this investigation, we present evidence that the situation is further complicated at slow growth rates. This is because an appreciable proportion of cells in the population (up to $40 \%$ ) are not continuously proliferating, but have stopped dividing in G1, and adopted stationary phase characteristics. A major implication of the presence of non-dividing cells at slow growth rates is that the dilution rate is not equal to the specific growth rate of the dividing cells. Consequently, the presence of non-dividing cells must be taken into consideration in assessing the behaviour of cells at different growth rates.

\section{METHODS}

Organism and growth conditions. Saccharomyces cerevisiae (strain X2180-1A) obtained from the Yeast Genetics Stock Center, Berkeley, Calif., U.S.A. was grown in medium containing $\left(\mathrm{g} \mathrm{l}^{-1}\right)$ : yeast extract, $10 \cdot 0$; bactopeptone, $10.0 ;$ glucose, $10.0 ;\left(\mathrm{NH}_{4}\right)_{2} \mathrm{SO}_{4}, 5.0 ;\left(\mathrm{NH}_{4}\right)_{2} \mathrm{HPO}_{4}, 2.0 ; \mathrm{MgSO}_{4}, 1.0$ and adenine at $100 \mathrm{mg} \mathrm{l}^{-1}$. The pH of the medium was adjusted to $5 \cdot 5$ with $1 \mathrm{M}-\mathrm{HCl}$.

Continuous culture was carried out in a 1 litre (Quickfit, Baird \& Tatlock) chemostat vessel with a working volume of $200 \mathrm{ml}$. The volume within the vessel was maintained by a stainless steel pipe entering the vessel near the liquid surface. The air pressure in the vessel was used to force excess liquid through the pipe. The culture was agitated with a magnetic stirrer bar and aerated at a rate of 0.451 air $\mathrm{min}^{-1}$. Incoming nutrient was pumped to the fermenter by means of a peristaltic pump (LKB) and foaming was prevented by the addition of antifoam (polypropylene glycol, BDH) injected into the vessel at $12 \mathrm{~h}$ intervals. The temperature was maintained at $24^{\circ} \mathrm{C}$.

Estimation of cell numbers and volumes. These were determined using a Coulter counter (model ZB1) and Channelyzer C1000 (Coulter Electronics Ltd, Dunstable, Beds, U.K.). A $70 \mu \mathrm{m}$ aperture diameter orifice was used for counting and sizing. Sample dilutions were made in Isoton (Coulter Electronics) after sonication, for $12 \mathrm{~s}$ at an 
amplitude of $18 \mu \mathrm{m}$, in an MSE Soniprep ultrasonic disintegrator. Size frequency distributions were obtained on paper tape and used for computer analysis (Bazin et al., 1975).

Preparation and analysis of phase-light cells. Preparations of phase-light cells were obtained by subjecting chemostat samples to cell wall digestion. Phase-dark cells were sensitive to this treatment, forming protoplasts and lysing, whereas phase-light cells remained intact. Cells $\left(3 \times 10^{7}\right)$ were treated with $3 \mathrm{ml}$ enzyme preparation SP234 (3 mg ml $\mathrm{mg}^{-1}$ in distilled water and filter-sterilized using a membrane filter with $0.45 \mu \mathrm{m}$ pore size) (Novo Enzyme Products Ltd, Windsor, U.K.), $0.1 \mathrm{ml} 1 \mathrm{~m}$-mercaptoethanol and $0.1 \mathrm{ml}$ Suc d'Helix (Industrie Biologique Francaise, Paris, France). The cells were incubated at $24^{\circ} \mathrm{C}$. Samples $(0.1 \mathrm{ml})$ were diluted in Isoton for analysis with the Coulter counter and Channelyzer. Cell wall digestion was monitored by following cell numbers until no further decrease was observed (about $30 \mathrm{~min}$ ). When wall digestion was complete, the remaining cells were washed in distilled water and stained with calcofluor (see below) for bud scar analysis.

Bud scar analysis. Cells were stained in a $2 \%(\mathrm{w} / \mathrm{v})$ calcofluor (American Cyanamid Co.) solution. Calcofluor is an optical brightener dye, which is highly specific for chitin, and enabled the bud scars and hence age of the cells to be analysed optically using a Zeiss UV microscope (Carter \& Jagadish, 1978a). The percentage of budded cells was estimated and at least 500 cells in each sample were classified according to age (Carter \& Jagadish, $1978 a$ ).

\section{RESULTS}

\section{Existence of phase-dark and phase-light cells in the chemostat}

Examination of stationary and exponential phase cells in batch culture using phase contrast optics revealed that the former are phase-light, whereas the latter are phase-dark (Fig. $1 a, b)$. We have examined the phase characteristics of cells at various growth rates in chemostat cultures of $S$. cerevisiae. At fast growth rates, the cells were phase-dark, resembling exponential phase cells; at slow growth rates however, there were phase-dark and phase-light cells as shown in Fig. 1(c). The phase-light cells were predominantly unbudded but a few budded cells were observed, which always had a phase-dark bud. The frequency of phase-light cells did not become significant until mass doubling times longer than $4.5 \mathrm{~h}$ (Fig. 2) were reached. The percentage of phase-light cells then increased for doubling times up to $8 \mathrm{~h}$ and no further increase was observed at the very slow growth rates (Fig. 2). The appearance of the phase-light cells was found to coincide with the growth rate at which the cell numbers $\mathrm{ml}^{-1}$ become independent of the growth rate (Fig. 2).

\section{Characteristics of phase-light cells from chemostat culture}

Exponential phase cells are sensitive to cell wall-degrading enzymes, whereas stationary phase cells are quite resistant (Piedra \& Herrera, 1976). Cells cultured at different mass doubling times in the chemostat were treated with cell wall-degrading enzymes and the percentage of cells in the population that survived the treatment was noted (Table 1). The percentage of cells that survived the treatment was similar to the percentage of phase-light cells observed microscopically (Table 1). Furthermore, those surviving cells were all phase-light under the phase contrast microscope.

Cell volume distributions before and after enzyme treatment were used to estimate the percentage of cells that survived the treatment. The area under the size distribution of surviving cells was expressed as a percentage of the area under the original volume distribution. It was found that at a mass doubling time of $3.7 \mathrm{~h}$ very few cells were left after treatment (Fig. 3). At mass doubling times of $5.7 \mathrm{~h}$ and $13.1 \mathrm{~h}$, however, the size distributions indicated that $33.6 \%$ and $30.5 \%$, respectively of the original cells were resistant to cell wall degradation. It can be concluded from these experiments that the phase-light cells in the chemostat cultures are showing stationary phase behaviour with respect to cell wall digestion.

\section{Which cells become phase-light?}

A comparison of the age classification of phase-light cells and phase-dark cells from different steady states is shown in Table 2 . It is clear that the phase-light cells were predominantly age 0 (Table 2) and non-dividing (Table 3). There was also a small percentage of cells of age 1 or greater that exhibit phase-light characteristics. This could mean that any cell can enter the phase-light state but that age 0 cells have the greatest probability of doing so. Alternatively, it is 

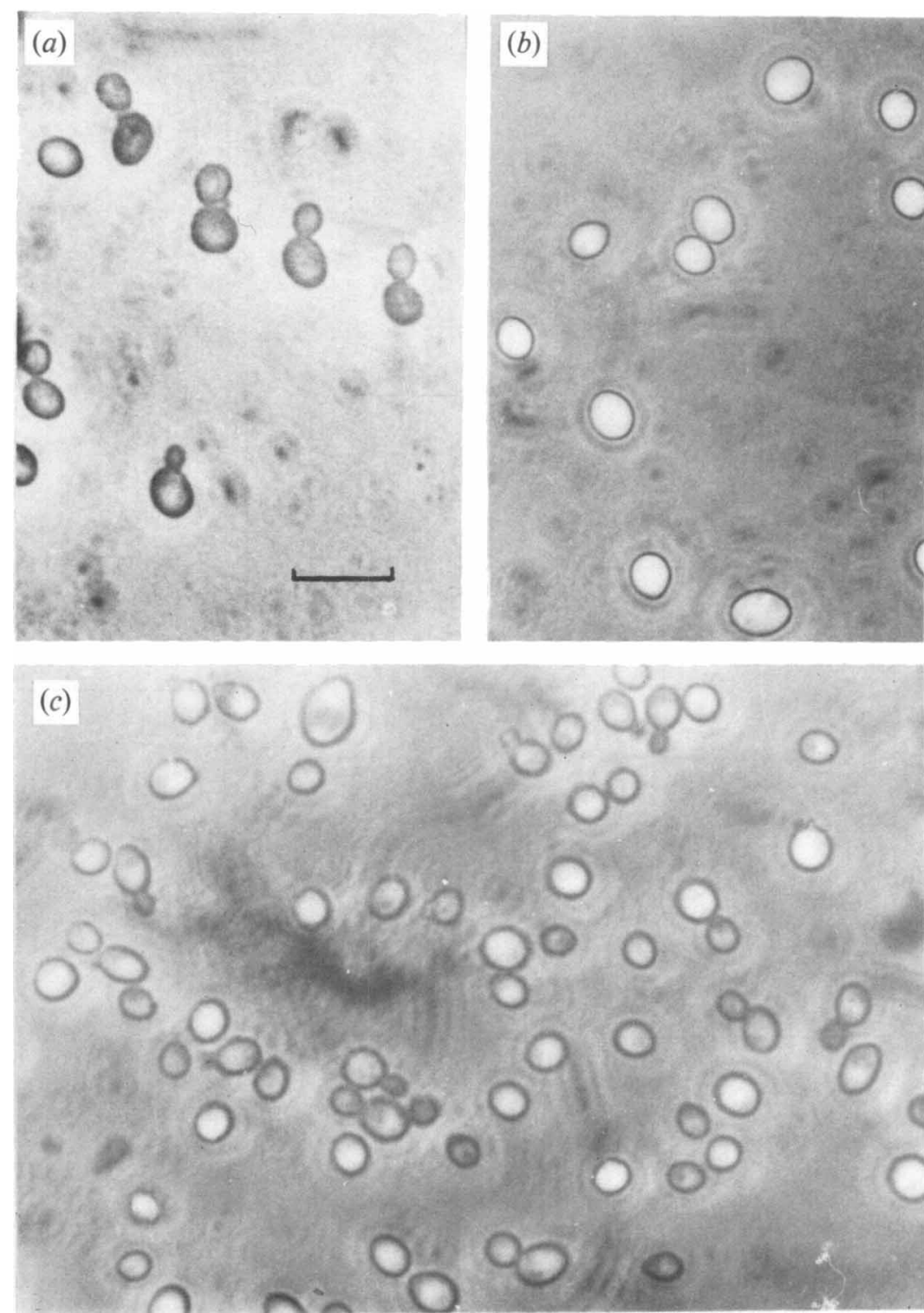

Fig. 1. Phase contrast micrographs of $S$. cerevisiae cells. (a) Exponentially growing cells are phase-dark, $(b)$ stationary phase cells are phase-light and $(c)$ a chemostat culture (mass doubling time, $8 \mathrm{~h}$ ) showing phase-dark and phase-light cells. The bar marker represents $10 \mu \mathrm{m}$.

Table 1. A comparison of cells surviving cell wall degradation and phase-light cells observed microscopically in chemostat cultures of $S$. cerevisiae

$\begin{array}{ccr}\begin{array}{c}\text { Mass doubling } \\ \text { time, } t_{\mathrm{d}}(\mathrm{h})\end{array} & \begin{array}{c}\text { Cells surviving cell } \\ \text { wall degradation (\%) }\end{array} & \begin{array}{c}\text { Phase-light } \\ \text { from microscope } \\ (\%)\end{array} \\ 3.3 & 8.7 & 4.0 \\ 3.7 & 5 \cdot 1 & 5 \cdot 0 \\ 5.5 & 33.0 & 20 \cdot 0 \\ 5.7 & 33.6 & 28 \cdot 0 \\ 11.2 & 42.2 & 38.3 \\ 13.0 & 30.5 & 29.7\end{array}$




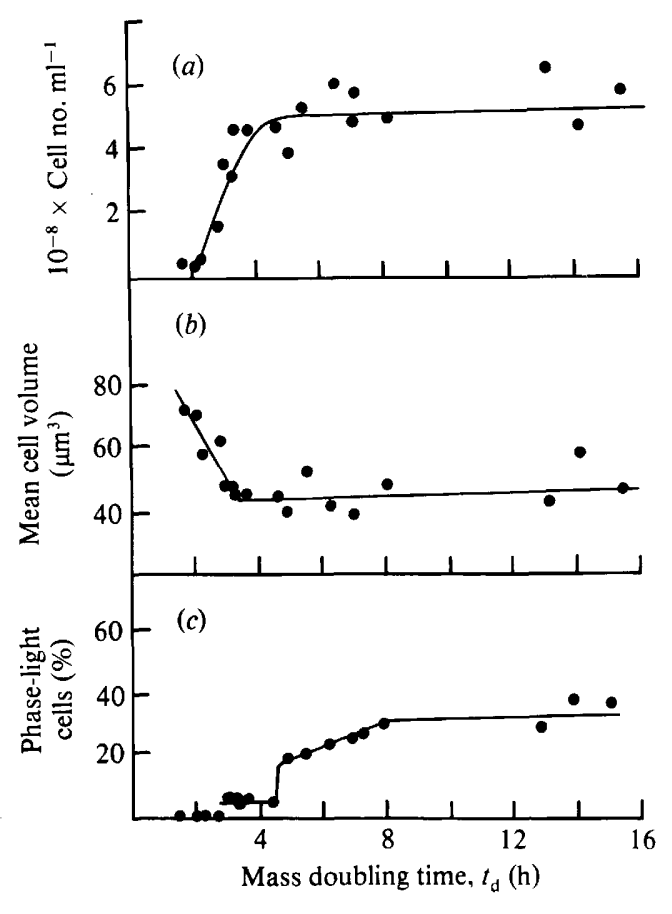

Fig. 2

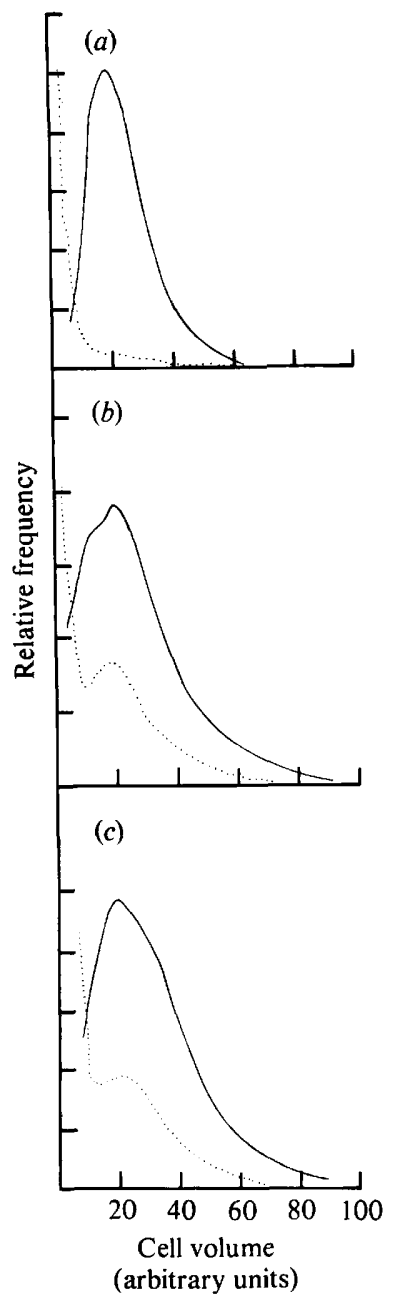

Fig. 3

Fig. 2. Growth of $S$. cerevisiae in glucose-limited chemostat culture. (a) Cell numbers, $(b)$ mean cell volumes and $(c)$ phase-light cells, expressed as a percentage of the total cell numbers.

Fig. 3. Cell volume distributions for $S$. cerevisiae before $(-)$ and after $(\cdots)$ cell wall digestion for cultures with mass doubling times $(a) 3.7 \mathrm{~h},(b) 5.7 \mathrm{~h}$ and $(c) 13.1 \mathrm{~h}$. The volume distributions of the phase-light cells $(\cdots)$ represent $(a) 5.1 \%$, (b) $33.6 \%$ and $(c) 30.5 \%$ of the original cell population.

Table 2. A comparison of age distributions of phase-dark and phase-light cells in the population for representative chemostat samples of $S$. cerevisiae

\begin{tabular}{|c|c|c|c|c|c|c|c|}
\hline \multirow{2}{*}{$\begin{array}{l}\text { Mass doubling } \\
\text { time } t_{\mathrm{d}}(\mathrm{h})\end{array}$} & \multirow{2}{*}{$\begin{array}{l}\text { Phase-light } \\
\text { cells* }(\%)\end{array}$} & \multicolumn{3}{|c|}{ Phase-dark cells $(\%)$} & \multicolumn{3}{|c|}{ Phase-light cells $(\%)$} \\
\hline & & Age 0 & Age 1 & Age $>1$ & Age 0 & Age 1 & Age $>1$ \\
\hline $3 \cdot 7$ & $5 \cdot 0$ & $62 \cdot 2$ & 18.4 & $14 \cdot 4$ & $3 \cdot 8$ & 0.4 & $0 \cdot 8$ \\
\hline $5 \cdot 5$ & $20 \cdot 0$ & $50 \cdot 6$ & $17 \cdot 2$ & $12 \cdot 2$ & $15 \cdot 6$ & 1.8 & $2 \cdot 6$ \\
\hline $6 \cdot 4$ & $24 \cdot 3$ & $44 \cdot 0$ & $16 \cdot 7$ & $15 \cdot 0$ & $21 \cdot 0$ & $2 \cdot 3$ & 1.0 \\
\hline $13 \cdot 1$ & $29 \cdot 7$ & $39 \cdot 5$ & $19 \cdot 1$ & $11 \cdot 7$ & $25 \cdot 5$ & 1.9 & $2 \cdot 3$ \\
\hline $14 \cdot 1$ & $37 \cdot 5$ & $35 \cdot 7$ & $13 \cdot 2$ & $13 \cdot 6$ & $33 \cdot 3$ & 1.8 & $2 \cdot 4$ \\
\hline
\end{tabular}

* From microscope count. 
Table 3. A comparison of the frequency of budded cells in phase-light and phase-dark populations at different mass doubling times in chemostat cultures of $S$. cerevisiae

\begin{tabular}{|c|c|c|c|}
\hline \multirow{2}{*}{$\begin{array}{l}\text { Mass doubling } \\
\text { time } t_{\mathrm{d}}(\mathrm{h})\end{array}$} & \multirow{2}{*}{$\begin{array}{l}\text { Phase-light } \\
\text { cells* }(\%)\end{array}$} & \multicolumn{2}{|c|}{ Budded cells ( $\%$ ) } \\
\hline & & Phase-light & Phase-dark \\
\hline $3 \cdot 7$ & $5 \cdot 0$ & $17 \cdot 6$ & $59 \cdot 1$ \\
\hline $5 \cdot 5$ & $20 \cdot 0$ & $10 \cdot 6$ & $45 \cdot 2$ \\
\hline 6.4 & $24 \cdot 3$ & 3.5 & $41 \cdot 1$ \\
\hline $14 \cdot 1$ & $37 \cdot 5$ & $4 \cdot 7$ & $41 \cdot 5$ \\
\hline
\end{tabular}

possible that only age 0 cells enter the phase-light state, but that a few subsequently re-enter the cycle and proliferate but retain the phase-light characteristic. The latter interpretation is supported by the observation that those phase-light cells which were budded had a phase-dark bud. It appears that phase-light cells can subsequently produce phase-dark daughters (from the dark buds) but that the parent portion of the cell maintains its phase-light appearance. This suggests that the phase-light appearance is a property of the cell wall; an interpretation that is consistent with its characteristics with regard to cell wall degrading enzymes.

The results (Table 2) further show an increasing tendency for age 0 cells to become phase-light as the growth rate declines, the percentage of age 0 phase-light cells increasing from 3.8 to 33.3 whilst the percentage of age 0 phase-dark cells decreased from 62.2 to 35.7 with decreasing growth rate.

The percentage of budded cells in the phase-light and phase-dark populations is shown in Table 3. In all cases the bud was phase-dark. At slow growth rates the phase-dark cells proliferated, whereas the phase-light cells showed very low frequencies of budding (Table 3). The percentage of budding in the phase-light population, however, increased at fast growth rates, suggesting that there was a greater probability of phase-light cells leaving this state at faster rather than slower growth rates. At all growth rates, it was found that there were more budded age 1 cells than age 0 phase-light cells indicating that age 1 parents have a greater ability to leave the phase-light state than younger daughter cells.

\section{Effect of phase light cells on the specific growth rate of the culture}

The occurrence of non-dividing cells, whose growth rate is zero or minimal, has implications for the specific growth rate of the proliferating cells in the culture, since the apparent specific growth rate for the whole population does not reflect the specific growth rate of all the cells. At fast growth rates, the numbers of phase-light cells are not sufficient to cause a significant difference between the actual and apparent growth rates of the phase-dark cells. At slow growth rates, however, the phase-dark cells must maintain a faster mass doubling time than the overall specific growth rate for the population in order to maintain the steady state. Table 4 shows the actual and apparent mass doubling times for the phase-dark cells from representative samples, calculated using the assumption that there is negligible contribution to the overall specific growth rate from the phase-light cells. It can be seen that the actual mass doubling time of the phase-dark cells is $9.2 \mathrm{~h}$ when the population mass doubling time is $13.1 \mathrm{~h}$ and does not exceed $9.8 \mathrm{~h}$ even when the population mass doubling time is $15.4 \mathrm{~h}$.

Pirt's (1975) model for viable and non-viable growth in chemostat cultures can be used to determine whether the probability of cells showing phase-light characteristics increases at slow growth rates. Assuming that the growth rates of the phase-light cells is negligible in comparison with that of the phase-dark cells, it can be seen that the probability of formation of the former per unit time was constant for mass doubling times between $4.5 \mathrm{~h}$ and $8 \mathrm{~h}$ (Fig. 4). At faster growth rates, the rate of production of phase-light cells was negligible. At mass doubling times longer than $8 \mathrm{~h}$, it is difficult to draw any firm conclusions except that the probability of formation of phase-light cells per unit time did not increase at such slow growth rates. This is perhaps not surprising since, in a population containing proliferating cells, some phase-dark 
Table 4. A comparison of apparent and actual mass doubling times for phase-dark cells from representative chemostat samples of $S$. cerevisiae

The actual mass doubling time $\left(t_{\mathrm{d}}{ }^{\prime}\right)$ was calculated from $\mu^{\prime}=D / N_{1}$ where $\mu^{\prime}$ is the specific growth rate of the phase-dark cells, $D$ is the dilution rate, $N_{1}$ is the fraction of phase-dark cells and $N_{2}$ is the fraction of phase-light cells (Pirt, 1975).

$\begin{array}{ccc}\begin{array}{c}\text { Apparent mass } \\ \text { doubling time } \\ t_{\mathrm{d}}(\mathrm{h})\end{array} & \begin{array}{c}\text { Actual mass } \\ \text { doubling time } \\ \boldsymbol{t}_{\mathrm{d}}{ }^{\prime}(\mathrm{h})\end{array} & \begin{array}{c}\text { Fraction of } \\ \text { phase-light } \\ \text { cells } N_{2}\end{array} \\ 2 \cdot 1 & 2 \cdot 1 & 0 \\ 3.7 & 3 \cdot 5 & 0.05 \\ 5 \cdot 5 & 4 \cdot 4 & 0 \cdot 20 \\ 6 \cdot 4 & 4.9 & 0 \cdot 24 \\ 7 \cdot 1 & 5 \cdot 2 & 0 \cdot 26 \\ 8 \cdot 0 & 5 \cdot 8 & 0.28 \\ 13 \cdot 1 & 9 \cdot 2 & 0.30 \\ 14 \cdot 1 & 8.9 & 0.38 \\ 15.4 & 9.8 & 0.37\end{array}$

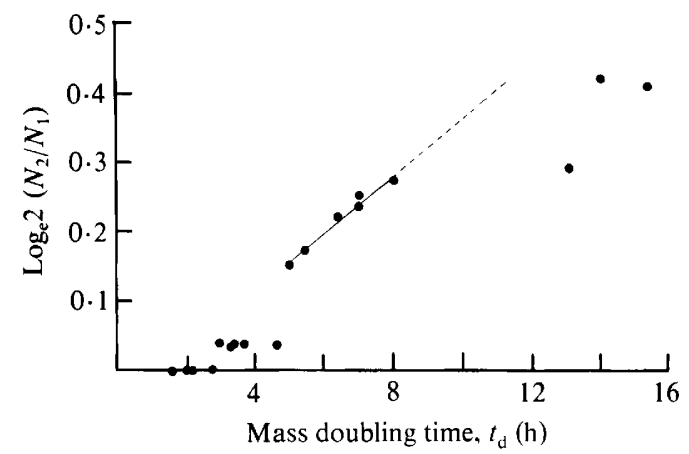

Fig. 4. Rate of formation of phase-light cells $(K)$. Phase-light cells as a fraction of the phase-dark cells $\left(N_{2} / N_{1}\right)$ are shown for different mass doubling times $\left(t_{\mathrm{d}}\right)$ in chemostat cultures of $S$. cerevisiae. The relationship was derived using the following equation: $N_{2} / N_{1}=K t_{\mathrm{d}} / \log _{\mathrm{e}} 2$.

cells must be produced and there is obviously a limit to the number of phase-light cells that can be observed in the chemostat under these conditions. The tendency for age 0 cells to become phase-light (Table 2) implies that the phase-dark population must contain a greater proportion of older proliferating cells than would normally be expected. The latter observation has been verified by age distribution analysis which has shown an increased frequency of cells in the older age classes at the slow growth rates.

\section{DISCUSSION}

This study shows that at slow growth rates in glucose-limited chemostat culture $S$. cerevisiae populations can be subdivided into two distinct physiological classes. Kuenzi (quoted in Fiechter, 1975) observed the simultaneous existence of phase-light and phase-dark cells in such cultures, but the significance of the phenomenon is not generally appreciated. The data presented here strongly suggest that phase-light cells are equivalent to the stationary phase cells seen in batch cultures upon nutrient depletion. Phase-dark cells, on the other hand, are equivalent to cells growing exponentially in batch culture in the presence of adequate exogenous nutrients.

Our results have three major consequences. The first is that the actively proliferating (phasedark) section of a split population has a specific growth rate that is greater than the dilution rate 
at doubling times greater than $4.5 \mathrm{~h}$ (Table 4). The second is that metabolic changes that occur at low dilution rates may reflect alterations in the proportion of proliferating (phase-dark) and nonproliferating (phase-light) cells, rather than alterations in the growth rate of individual cells. The third consequence of the data is to suggest the existence of a mechanism for the creation and maintenance of the observed heterogeneity of cell types.

Phase-light cells are predominantly those cells that have not previously budded, i.e. daughter cells (Table 2). Previous studies in this and other laboratories have shown that daughter cells are distinct from cells that have previously divided (parents) at slow growth rates with regard to their cell cycle characteristics (Hartwell \& Unger, 1977; Jagadish et al., 1977; Carter \& Jagadish, 1978a; Lord \& Wheals, 1980). Briefly, daughter cells at slow growth rates in both batch and chemostat culture spend a longer time in the Gl phase of the cycle than do parent cells. This phenomenon has been associated with the existence of a size control over exit from G1, since daughter cells are significantly smaller than their parents at slow growth rates (Hartwell \& Unger, 1977; Jagadish et al., 1977; Carter \& Jagadish, 1978b; Lorincz \& Carter, 1979; Lord \& Wheals, 1980). Entry into stationary phase in batch culture is a G1-specific event, and so the preferential occurrence of daughter cells in the phase-light population is consistent with the idea that formation of phase-light cells represents $\mathrm{Gl}$ cell cycle specific differentiation into stationary phase.

Phase-light cells first appear in the chemostat at mass doubling times longer than $4.5 \mathrm{~h}$, coincident with the point at which cell numbers become independent of dilution rates (Fig. 2) and biomass yield is maximal (Fiechter, 1975). At growth rates slower than $4.5 \mathrm{~h}$, there is no exogenous glucose in the culture medium and transition of the entire population into stationary phase is only prevented by the continuous influx of fresh medium. Although theoretically this is instantaneously distributed to all the cells in the population it is unlikely in practice that this is true. One explanation for the differentiation phenomenon is that at slow growth rates an increasing fraction of the population is effectively starved for glucose and enters the stationary phase. If the level of glucose availability required for stationary phase entry is lower than that for stationary phase exit, the low frequency of phase-light cells re-entering the cell cycle can be understood. Our observation that at slow growth rates a proportion of the population differentiates into non-proliferating, stationary phase cells suggests that the population is growing at near threshold conditions for a switch to alternative developmental pathways to occur. This may be a more general phenomenon, since McDonald et al. (1982) have observed that at slow growth rates in a glucose-limited chemostat the fission yeast Schizosaccharomyces pombe conjugates and sporulates. Two filamentous moulds, Penicillium chrysogenum (Righelato et al., 1968) and Aspergillus niger ( $\mathrm{Ng}$ et al., 1972), have been observed to sporulate at very low growth rates in carbon-limited culture. The phenomenon is not restricted to eukaryotes as Dawes \& Thornley (1970) have noted sporulation in Bacillus subtilis at slow growth rates. In these instances, the alternative development pathway can be readily recognized by morphological changes. In some instances such as cessation of division and adoption of stationary phase characteristics, the alternative developmental pathways are difficult to distinguish and may have gone undetected.

\section{REFERENCES}

Bazin, M. J., Richards, L. \& Saunders, P. T. (1975). Automated analysis of microbial size distributions. In Proceedings of the Tenth Coulter Conference, London. pp. 1-15

CARTER, B. L. A. \& JAgadish, M. N. (1978a). The relationship between cell size and cell division in the yeast Saccharomyces cerevisiae. Experimental Cell Research 112, 15-24.

CARTER, B. L. A. \& Jagadish, M. N. (1978b). Control of cell division in the yeast Saccharomyces cerevisiae cultured at different growth rates. Experimental Cell Research 112, 373-383.

Dawes, I. W. \& Thornley, J. H. M. (1970). Sporulation of Bacillus subtilis. Theoretical and experimental studies in continuous culture systems. Journal of General Microbiology 62, 49-66.

FIECHTER, A. (1975). Continuous cultivation of yeasts. Methods in Cell Biology 11, 97-130.

HaRTWELl, L. H. \& UNGER, M. W. (1977). Unequal division in Saccharomyces cerevisiae and its implica- 
tions for the control of cell division. Journal of Cell Biology 75, 422-435.

JAGADISH, M. N. \& CARTeR, B. L. A. (1977). Genetic control of cell division in yeast cultured at different growth rates. Nature, London 269, 145-147.

JAGADISH, M. N., Lorincz, A. \& CARTER, B. L. A. (1977). Cell size and cell division in yeast cultured at different growth rates. FEMS Microbiology Letters 2 , 235-237.

Johnston, G. C., ERHARDT, C. W., LoRINCZ, A. \& CARTER, B. L. A. (1979). Regulation of cell size in the yeast Saccharomyces cerevisiae. Journal of Bacteriology 137, 1-5.

LORD, P. G. \& WheAls, A. E. (1980). Asymmetrical division of Saccharomyces cerevisiae. Journal of Bacteriology 142, 808-818.

LORINCZ, A. \& CARTER, B. L. A. (1979). Control of cell size at bud initiation in Saccharomyces cerevisiae. Journal of General Microbiology 113, 287-295.

McDonald, I. J., Calleja, G. B. \& Johnson, B. F. (1982). Conjugation in chemostat cultures of Schizosaccharomyces pombe. Journal of General Microbiology 128, 1981-1987.
VON MEYENBURG, H. K. (1968). The budding cycle of Saccharomyces cerevisiae. Pathologia et microbiologica 31, 117-127.

NG, A. M. L., Smith, J. E. \& ANDerson, J. G. (1972). Changes in carbon catabolic pathways during the synchronous development of Aspergillus niger. Journal of General Microbiology 71, 495-504.

Piedra, D. \& Herrera, L. (1976). Selection of auxotrophic mutants in Saccharomyces cerevisiae by a snail enzyme digestion method. Folia microbiologica 21, 337-341.

PIRT, S. J. (1975). In Principles of Microbe and Cell Cultivation. Oxford: Blackwell Scientific Publications.

Righelato, R. C., Trinci, A. P. J., Pirt, S. J. \& Peat, A. (1968). The influence of maintenance energy and growth rate on the metabolic activity, morphology and conidiation of Penicillium chrysogenum. Journal of General Microbiology 50, 399-412.

Thompson, P. W. \& WheAls, A. E. (1980). Asymmetrical division of Saccharomyces cerevisiae in glucoselimited chemostat culture. Journal of General Microbiology 121, 401-409. 